\section{PENGGUNAAN RASIO KEUANGAN DAN GOOD CORPORATE GOVERNANCE UNTUK MEMPREDIKSI FINANCIAL DISTRESS}

\author{
Endriz Devianti Fahlevi*) dan Hasan Mukhibad \\ Jurusan Akuntansi, Fakultas Ekonomi, Universitas Negeri Semarang \\ Gedung Lantai 2 FE UNNES, Kampus Sekaran, Gunungpati, Semarang, Indonesia. \\ E-mail Koresponden: endrizfahlevi@gmail.com
}

\begin{abstract}
The study aimed to analyze the effect of financial ratios and the implementation of good corporate governance to predict financial distress. The population in this study were savings and credit cooperatives listed in the Cooperative Office of Semarang Regency during the period of $2014-2016$ that is 42 cooperative. The sample was chosen by purposive sampling method with some criterias so obtained 26 cooperative (78 unit of analysis during three years of research). The data analysis technique used was logistic regression analysis that processed with SPSS 20. Hypothesis testing is done by logistic regression test, because the dependent variable in the study is dichotomy using dummy variables. The use of dummy variables is used to make it easier to interpret cooperatives that experience financial distress and cooperatives that do not experience financial distress The result of this study showed that liquidity has no effect on financial distress, profitability has no effect on financial distress, leverage has no effect on financial distress. Role of members has no effect on financial distress and presence of administrators has no effect on financial distress, while presence of supervisor has a negative and significant effect on financial distress. The result of this study can be concluded that prediction financial distress can be affected by presence of supervisor in the cooperative.
\end{abstract}

Keywords: Leverage; Liquidity; Presence of Administrators; Presence of Supervisor; Profitability; Role of Members

\section{PENDAHULUAN}

Kondisi ekonomi di Indonesia yang tidak stabil dapat menyebabkan kesulitan pada perusahaan untuk tetap berjalan dalam mempertahankan persaingan yang sangat ketat. Perkembangan perekonomian Indonesia saat ini menuntut untuk perusahaan harus melakukan inovasi dan memperluas pangsa sehingga perusahaan mampu bertahan dan bersaing (Hadi, 2014). Financial distress adalah keadaan dimana perusahaan mengalami kemunduran dalam hal keuangan. Fenomena dari financial distress yaitu perusahaan cenderung akan mengalami masalah likuiditas dimana perusahaan tidak lagi mampu memenuhi kewajibannya (Hanifah \& Purwanto, 2013). Kondisi financial distress lainnya juga ditandai dengan adanya perusahaan yang mengalami delisting dari Bursa Efek Indonesia (Pranowo, Achasani, \& Manurung, 2010).

Yokono (2016) dalam website (www.kaskus.co.id, 2016), menyatakan bahwa pada tahun 2016 terdapat tujuh perusahaan yang mengalami masalah kebangkrutan di Indonesia, dimana perusahaan tersebut termasuk perusahaan bisnis berskala internasional yang melibatkan investor asing. Salah satu perusahaan yang mengalami kebangkrutan di Indonesia adalah Ford Motor Indonesia yang memiliki faktor kesulitan financial dan menjadi alasan terkuat bangkrutnya bisnis berlabel internasional tersebut. Faktor lainnya yang menyebabkan bisnis berskala
Diterima:

29 Juli 2018

Direvisi:

10 Agustus 2018

Disetujui:

24 Oktober 2018

Artikel ini tersedia di website: http:// ejournal.umm.ac.id/ index.php/jrak

Doi: 10.22219/ jrak.v8i2.34

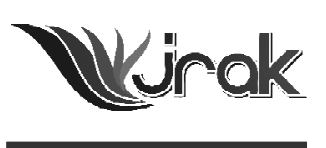

Jurnal Reviu Akuntansi dan Keuangan p-ISSN：2615-2223 e-ISSN: 2088-0685 Vol. 8 No. 2, Oktober 2018 Pp 147-158 
Penggunaan Rasio

Keuangan... internasional tersebut tidak mampu mempertahankan bisnisnya adalah karena kurangnya kontrol dalam menjalankan usaha serta manajemen perusahaan yang tidak efektif dan efisien.

Financial distress dapat juga terjadi pada koperasi simpan pinjam. Haryadi (2017) menyatakan bahwa sebanyak 100 koperasi di wilayah Kabupaten Semarang akan dibubarkan oleh Kementerian Koperasi dan Usaha Kecil Menengah karena koperasi tersebut memiliki masalah finansial. Koperasi yang banyak mengalami masalah yakni koperasi simpan pinjam. Hal ini dikarenakan pada koperasi masih mengalami minimnya pengawasan dalam jalannya operasional koperasi tersebut dan adanya permasalahan dimana koperasi tidak dapat mengembalikan dana anggota yang telah disimpan (Habibi, 2017). Pemilihan koperasi simpan pinjam wilayah Kabupaten Semarang dikarenakan masih rendahnya tingkat pelaporan transaksi keuangan yang dinyatakan oleh Pusat Pelaporan dan Analisis Transaksi Keuangan dan masih rendahnya penerapan good corporate governance dalam koperasi simpan pinjam. Selain itu, koperasi simpan pinjam juga belum memahami kajian mengenai financial distress.

Berdasarkan alasan - alasan tersebut dapat dikatakan bahwa pengembangan sistem financial distress dalam koperasi simpan pinjam diperlukan untuk mengetahui kondisi keuangan pada koperasi. Salah satu cara untuk mengetahui sebuah koperasi mengalami financial distress atau tidak, dengan melihat kinerja keuangan koperasi yang diukur dengan melalui laporan keuangan setiap tahunnya (Suhartiningsih \& Wirawati, 2017). Laporan keuangan dianalisa menggunakan rasio - rasio keuangan untuk menilai keadaan keuangan perusahaan di masa lalu, saat ini, dan kemungkinan di masa depan (Hadi, 2014).

Selain melihat dari rasio keuangannya koperasi juga harus melihat dari penerapan good corporate governance. Mekanisme good corporate governance memiliki tujuan untuk menciptakan nilai tambah untuk perusahaan dan semua pihak yang berkepentingan. Penerapan prinsip good corporate governance dalam koperasi diperlukan adanya kerjasama antara seluruh unsur good corporate governance dalam menjalankan hak dan kewajiban secara maksimal dimana manajemen, penanggung jawab kelompok, dan petugas penyuluh lapangan merupakan hal terpenting pada posisi top manajemen dimana anggota yang difungsikan sebagai pihak principals wajib mematuhi keputusan yang telah diambil oleh top manajemen (Iskandar, 2015). Adanya skandal kebangkrutan dikarenakan penerapan good corporate governance diabaikan, terutama pada prinsip transparansi, disclosure, dan akuntabilitas (Widhianningrum \& Amah, 2012).

Penelitian yang dilakukan oleh Almilia \& Kristijadi (2003), Zaki, Bah, \& Rao (2011), Pranowo et al. (2010), dan Uðurlu \& Aksoy (2006) menyatakan bahwa likuiditas berpengaruh secara signifikan terhadap financial distress. Hapsari (2012), Fitriyah \& Hariyati (2013), Baimwera \& Muriuki (2014), Lakshan \& Wijekoon (2013), dan Kusanti (2015) menyatakan bahwa likuiditas tidak berpengaruh terhadap financial distress. Zaki et al. (2011), Uðurlu \& Aksoy (2006), Baimwera \& Muriuki (2014), dan Aisyah, Kristanti, \& Zultilisna (2017) menyatakan bahwa profitabilitas berpengaruh secara signifikan terhadap financial distress. Lakshan \& Wijekoon (2013), Kusanti (2015), dan Pranowo et al. (2010) menyatakan bahwa profitabilitas tidak berpengaruh terhadap financial distress. Almilia \& Kristijadi (2003), Hapsari (2012), dan (Sukirno, Haryadi, \& Budiarti, 2014) menyatakan bahwa leverage berpengaruh secara signifikan terhadap financial distress. Baimwera \& Muriuki (2014), Kusanti (2015), Aisyah, Kristanti, \& Zultilisna (2017), dan Hadi (2014) menyatakan bahwa leverage tidak berpengaruh terhadap financial distress. adanya research gap tersebut, peneliti menambahkan penerapan good corporate governance yang diukur dari peran anggota, peran pengurus, dan peran pengawas dalam koperasi.

Tujuan penelitian yaitu untuk melihat pengaruh rasio keuangan dengan indikator likuiditas, profitabilitas, dan leverage terhadap prediksi financial distress pada koperasi simpan pinjam wilayah Kabupaten Semarang dan melihat 
pengaruh dari penerapan good corporate governance dengan indikator peran anggota, kehadiran pengurus dalam RAT, dan kehadiran pengawas dalam RAT terhadap prediksi financial distress. Penggunaan variabel likuiditas, profitabilitas dan leverage karena pengukuran rasio keuangan dan penerapan good corporate governance untuk melihat prediksi financial distress dalam koperasi simpan pinjam masih sangat jarang dilakukan.

Teori keagenan (agency theory) menurut Jensen dan Mekling (1976) dalam Widyasaputri (2012) hubungan keagenan digambarkan timbul karna adanya kontrak yang ditetapkan antara principal yang menggunakan agen untuk melaksanakan jasa yang menjadi kepentingan dalam hal terjadi pemisahan kepemilikan dan kontrol perusahaan. Teori sinyal merupakan tindakan yang dilakukan oleh manajer tingkat atas dan tidak masuk akal jika tindakan akan dilakukan oleh manajer tingkat bawah (Scott, 2012). Menurut Brigham \& Houston (2013) teori sinyal menjelaskan mengenai tindakan manajemen perusahaan yang memberikan petunjuk bagi investor tentang bagaimana manajemen memandang prospek perusahaan.

Likuiditas adalah kemampuan perusahaan dalam memenuhi kewajiban jangka pendek yang akan segera jatuh tempo (Hery, 2015). Sukirno et al. (2014) menyatakan bahwa prediksi financial distress dapat diukur dengan menggunakan rasio aktiva lancar terhadap jumlah aktiva. Current ratio merupakan indikator yang digunakan secara luas karena adanya jaminan terhadap kemungkinan rugi yang timbul dari usaha dengan cara merealisasikan aset lancar non kas menjadi kas.

Teori sinyal mendukung adanya pengaruh likuiditas terhadap financial distress. Teori ini digunakan sebagai dorongan perusahaan dalam memberikan informasi terkait sehat atau tidaknya keadaan keuangan dilihat dari laporan keuangan yang dihasilkan. Semakin tinggi nilai likuiditas dalam koperasi maka semakin baik koperasi dalam melunasi hutang jangka pendeknya, sehingga koperasi akan terhindar dari masalah financial distress dan mampu memberikan sinyal baik kepada para anggota atau pemilik modal dalam koperasi. Hal ini sejalan dengan Almilia \& Kristijadi (2003), Zaki, Bah, \& Rao (2011), Pranowo et al. (2010), dan Uðurlu \& Aksoy (2006). Berdasarkan dari uraian diatas maka dapat dikembangkan hipotesis sebagai berikut:

$\mathrm{H}_{1}$ : Likuiditas berpengaruh positif signifikan terhadap Financial DistresS

Profitabilitas adalah kemampuan perusahaan dalam menghasilkan laba (Hery, 2015). Profitabilitas merupakan salah satu indikator dalam pengukuran keberhasilan kinerja perusahaan dalam menghasilkan laba. Berdasarkan teori sinyal bahwa pengelola atau manajemen perusahaan memiliki tanggung jawab untuk memberikan hasil laporan keuangan dan laporan tahunan yang berisikan informasi - informasi keuangan perusahaan, dan kondisi perusahaan. Koperasi dengan nilai profitabilitas yang tinggi akan memberikan sinyal positif kepada pemilik atau pihak eksternal dan koperasi tersebut dapat dikatakan mampu memanfaatkan aset perusahaan secara efektif sehingga terjadi peningkatan pendapatan yang mempengaruhi besarnya laba yang dihasilkan.

Tingkat profitabilitas yang maksimal menunjukkan bahwa aset yang digunakan oleh koperasi telah dimanfaatkan secara optimal, sehingga koperasi mampu menghindari kelebihan atau pembengkakan biaya yang akan dikeluarkan. Dampak lain dari peningkatan profitabilitas yakni akan adanya penurunan kondisi financial distress. Hal ini sejalan dengan Zaki et al. (2011), Uðurlu \& Aksoy (2006), Baimwera \& Muriuki (2014), dan Aisyah, Kristanti, \& Zultilisna (2017). Berdasarkan dari uraian diatas maka dapat dikembangkan hipotesis sebagai berikut:

$\mathrm{H}_{2}$ : Profitabilitas berpengaruh negatif signifikan terhadap Financial Distress

Leverage adalah gambaran dari kemampuan perusahaan dalam memenuhi seluruh kewajibannya (Hery, 2015). Leverage yang diukur dengan menggunakan 
Penggunaan Rasio

Keuangan...

150 proporsi total hutang dengan total modal akan menghasilkan gambaran mengenai keadaan perusahaan pada suatu periode. Teori keagenan menjelaskan mengenai keberlangsungan hidup perusahaan berada ditangan agen dimana agen bertindak untuk memutuskan apakah perusahaan tersebut harus melakukan pendanaan dari pihak ketiga atau tidak. Teori sinyal digunakan untuk memberikan petunjuk mengenai prospek perusahaan tersebut, dimana keadaan sehat atau tidaknya perusahaan dapat dilihat pada hasil laporan keuangannya.

Semakin besar pembiayaan yang berasal dari pendanaan hutang maka kemungkinan koperasi tidak dapat memenuhi hutangnya juga semakin tinggi. Jika hutang yang tidak mampu dibayarkan dalam jumlah banyak maka akan menimbulkan masalah keuangan dalam kegiatan operasional koperasi. Permasalahan yang akan timbul saat koperasi memiliki masalah keuangan yakni akan menghasilkan sinyal buruk dan akan berdampak pada respon dari pihak pihak berkepentingan. Hal ini sejalan dengan Almilia \& Kristijadi (2003), Hapsari (2012), Rahmawati \& Khoiruddin (2017), Simanjutak, Farida, \& Aminah (2017) dan (Sukirno et al., 2014). Berdasarkan dari uraian diatas maka dapat dikembangkan hipotesis sebagai berikut:

\section{$\mathrm{H}_{3}:$ Leverage berpengaruh positif signifikan terhadap Financial Distress}

Anggota koperasi merupakan pemilik modal utama, sekaligus pemakai jasa unit usaha simpan pinjam koperasi (Iskandar, 2015). Keberhasilan dalam koperasi dipengaruhi oleh partisipasi anggota, sehingga semakin banyak anggota yang aktif maka kegiatan koperasi yang dijalankan dan perolehan sisa hasil usaha akan meningkat. Peran anggota koperasi diukur dengan menggunakan piutang yang dibagi dengan total aset. Semakin tinggi rasio piutang yang dihasilkan koperasi maka semakin baik peran anggota di koperasi yang melakukan transaksi peminjaman dana.

Teori agensi menjelaskan bahwa adanya hubungan kontrak antara pemilik dan pengelola perusahaan. Hubungan keagenan muncul karena adanya hubungan kerjasama antara pihak yang memberi wewenang (prinsipal) yaitu pemilik modal dengan pihak yang menerima wewenang (agen) yaitu manajer. Pada koperasi harus ada hubungan timbal balik antara rapat anggota, pengurus, dan manajer. Apabila peran anggota berjalan aktif maka keberlangsungan koperasi dapat dipastikan meningkat dan digunakan sebagai peningkatan potensi serta motif koperasi. Pada penelitian Cahyani (2015) menyatakan bahwa adanya pengaruh tidak langsung antara jumlah anggota terhadap perolehan hasil sisa usaha melalui partisipasi anggota, sehingga hal tersebut yang memungkinkan bahwa peran anggota berpengaruh negatif terhadap financial distress dalam koperasi. Berdasarkan dari uraian diatas maka dapat dikembangkan hipotesis sebagai berikut:

$\mathrm{H}_{4}$ : Peran Anggota berpengaruh negatif signifikan terhadap Financial Distress

Pengurus adalah pihak pengelola koperasi yang terdiri dari lima atau tujuh orang yang merupakan jabatan inti suatu organisasi (Iskandar, 2015). Pengurus bertugas untuk mengelola koperasi, memelihara kekayaan koperasi dan menjadi kuasa rapat anggota yang mengajukan laporan keuangan dan pertanggungjawabannya. Efektifitas pengurus dapat dilihat dari seberapa banyak pengurus yang hadir dalam rapat anggota tahunan untuk membahas mengenai hasil laporan keuangan. Semakin banyak pengurus yang hadir maka semakin tinggi tingkat pertanggungjawaban pengurus terhadap hasil laporan keuangan yang akan memberikan sinyal baik atau buruk untuk diberitahukan kepada pihak - pihak yang berkepentingan.

Teori agensi menjelaskan bahwa adanya hubungan antara pihak manajemen dan pemilik yang akan memicu terjadinya konflik dalam organisasi. Konflik tersebut dapat diminimalisir dengan adanya penerapan corporate governance yang baik. Semakin baik penerapan corporate governance dalam koperasi maka dapat mening- 
katkan motivasi kerja untuk pengurus dalam mengelola koperasi. Pengurus dalam penelitian ini diproksikan dengan variabel direktur independen pada penelitian Li, Wang, \& Deng (2008), dimana penelitian tersebut menyatakan bahwa direktur independen berpengaruh signifikan terhadap financial distress. Berdasarkan dari uraian diatas maka dapat dikembangkan hipotesis sebagai berikut:

$\mathrm{H}_{5}$ : Kehadiran Pengurus dalam RAT berpengaruh negatif signifikan terhadap Financial Distress

Pengawas adalah pihak yang bertugas untuk mengawasi jalannya pelaksanaan kebijaksanaan dan pengelolaan koperasi yang dilakukan oleh pengurus (Iskandar, 2015). Efektifitas pengawas dilihat dari seberapa banyak pengawas yang hadir dalam rapat anggota tahunan untuk memonitoring dan mengevaluasi hasil kinerja pengurus. Semakin banyak pengawas yang hadir dalam rapat anggota maka semakin tinggi tingkat pengawasan yang dilakukan pengawas terhadap hasil kinerja pengurus dalam mengelola aset koperasi.

Teori agensi menjelaskan bahwa hubungan yang baik antara prinsipal dengan agennya dipengaruhi dari seberapa baiknya penerapan corporate governance dalam suatu perusahaan. Sama halnya dengan pengurus, pengawas pada koperasi juga perlu penerapan corporate governance yang baik untuk memicu motivasi kerja dalam melakukan pengawasan dan evaluasi laporan keuangan yang telah dihasilkan oleh pengurus. Semakin baik corporate governance yang diterapkan maka semakin baik pula hasil monitoring dan evaluasi yang dihasilkan. Pengawas dalam penelitian ini diproksikan sebagai dewan komisaris dan komisaris independen yang keberadaannya dijadikan sebagai mediator, apabila komisaris independen tidak mampu memprediksi financial distress maka kemungkinan keberadaannya tidak mampu meminimalisir konflik keagenan yang terjadi. Hal ini sejalan dengan Hadi (2014) dan Fathonah (2016). Berdasarkan dari uraian diatas maka dapat dikembangkan hipotesis sebagai berikut:

$\mathrm{H}_{6}$ : Kehadiran Pengawas dalam RAT berpengaruh negatif signifikan terhadap Financial Distress

\section{METODE PENELITIAN}

Jenis penelitian yang digunakan dalam penelitian ini adalah penelitian kuantitatif dengan menggunakan data sekunder. Populasi dalam penelitian ini adalah koperasi simpan pinjam yang terdaftar di Dinas Koperasi Kabupaten Semarang pada tahun 2014 - 2016 sebanyak 42 koperasi. Sampel penelitian dipilih dengan metode purposive sampling, diperoleh 26 koperasi dengan 78 unit analisis.

\begin{tabular}{clc}
\hline No & \multicolumn{1}{c}{ Keterangan } & Jumlah \\
\hline 1. & $\begin{array}{l}\text { Koperasi simpan pinjam yang terdatar di Dinas Koperasi } \\
\text { Kabupaten Semarang pada tahun 2014-2016 }\end{array}$ & 42 \\
2. & $\begin{array}{l}\text { Koperasi yang dinyatakan tidak aktif oleh Dinas Koperasi } \\
\text { Kabupaten Semarang }\end{array}$ & (3) \\
3. & $\begin{array}{l}\text { Koperasi yang tidak memiliki laporan keuangan per 31 } \\
\text { Desember dari tahun 2014-2016 }\end{array}$ & (13) \\
\hline Jumlah sampel penelitian & 26 \\
\hline Total unit analisis & 78 \\
\hline
\end{tabular}

Tabel 1 .

Rincian Pemilihan Sampel Penelitian

Variabel dependen penelitian ini adalah financial distress, variabel independennya adalah likuiditas, profitabilitas, leverage, peran anggota, kehadiran pengurus dalam RAT, dan kehadiran pengawas dalam RAT. Berikut ini adalah definisi operasional variabel penelitian dapat dilihat pada tabel 2. 


\section{Penggunaan \\ Rasio \\ Keuangan...}

\section{2}

\begin{tabular}{llll}
\hline No. & Variabel & \multicolumn{1}{c}{ Definisi Variabel } & \multicolumn{1}{c}{ Pengukuran } \\
\hline 1 & Financial & Financial Distress adalah & $I C R=\frac{\text { SHU }}{\text { Interest Expense }}$ \\
& DistresS & tahapan penurunan kondisi & ICR $<1$ maka financial distress
\end{tabular}
keuangan yang terjadi sebelum kebangkrutan atau likuidasi (Platt \& Platt, 2002).

dan akan diberi skor 1 , sedangkan jika hasil ICR $>1$ maka tidak mengalami financial distress dan akan diberi skor 0 . Hal ini mengacu pada Asquith, Gertner, \& Scharfstein (1994) CurrentRatio $=\frac{\text { Aktiva Lancar }}{\text { Kewajiban Lancar }}$ Hal tersebut mengacu pada Finnerty (1986) kemampuan perusahaan untuk melunasi kewajiban jangka pendek secara tepat waktu (Fitriyah \& Hariyati, 2013). Profitabilitas adalah kemampuan perusahaan dalam menghasilkan laba (Hery, 2015).

Profitabilitas $=\frac{\text { SHU }}{\text { Total Aktiva }}$

Hal tersebut mengacu pada

Finnerty (1986)

\begin{tabular}{|c|c|c|c|}
\hline 4 & Leverage & $\begin{array}{l}\text { Leverage adalah kemampuan } \\
\text { perusahaan dalam memenuhi } \\
\text { kewajibannya (Hery, 2015). }\end{array}$ & $\begin{array}{l}D E R=\frac{\text { Total Hutang }}{\text { Total Modal }} \\
\text { Hal tersebut mengacu pada } \\
\text { Finnerty (1986) }\end{array}$ \\
\hline 5 & $\begin{array}{l}\text { Peran } \\
\text { Anggota }\end{array}$ & $\begin{array}{l}\text { anggota koperasi merupakan } \\
\text { pemilik modal utama, sekaligus } \\
\text { nasabah pemakai jasa unit } \\
\text { usaha simpan pinjam koperasi } \\
\text { (Iskandar, 2015). }\end{array}$ & PeranAnggota $=\frac{\text { Piutang }}{\text { Total Aset }}$ \\
\hline 6 & $\begin{array}{l}\text { Kehadiran } \\
\text { Pengurus } \\
\text { dalam RAT }\end{array}$ & $\begin{array}{l}\text { pengurus koperasi adalah pihak } \\
\text { pengelola koperasi yang terdiri } \\
\text { dari lima atau tujuh orang yang } \\
\text { terdiri dari jabatan inti suatu } \\
\text { organisasi (Iskandar, 2015). }\end{array}$ & $\begin{array}{l}\text { Kehadiran Pengurus dalam RAT } \\
=\frac{\text { Pengurus } \text { hadir } \text { RAT }}{\text { Total Pengurus }}\end{array}$ \\
\hline 7 & $\begin{array}{l}\text { Kehadiran } \\
\text { Pengawas } \\
\text { dalam RAT }\end{array}$ & $\begin{array}{l}\text { pengawas koperasi adalah pihak } \\
\text { yang bertugas mengawasi } \\
\text { jalannya pelaksanaan } \\
\text { kebijaksanaan dan pengelolaan } \\
\text { koperasi yang dilakukan } \\
\text { pengurus (Iskandar, 2015). }\end{array}$ & $\begin{array}{l}\text { Kehadiran Pengawas dalam RAT } \\
=\frac{\text { Pengawas hadir } R A T}{\text { Total } \text { Pengawas }}\end{array}$ \\
\hline
\end{tabular}

Data yang digunakan adalah data sekunder, sehingga pengumpulan data diperoleh dengan teknik dokumenter dan studi pustaka. Penelitian ini menggunakan laporan tahunan koperasi yang terdaftar di Dinas Koperasi Kabupaten Semarang pada tahun 2014 - 2016 dengan cara meminta data secara langsung pada setiap koperasi yang telah dijadikan sampel penelitian. Pengujian hipotesis dilakukan dengan uji regresi logistik, karena variabel dependen dalam penelitian bersifat dikotomi dengan menggunakan variabel dummy. Penggunaan variabel dummy digunakan untuk mempermudah dalam menginterpretasikan koperasi yang mengalami financial distress dan koperasi yang tidak mengalami financial distress. Pada regresi logistik tidak memerlukan uji normalitas namun hanya menggunakan uji multikolinearitas untuk uji asumsi klasiknya.

Berikut ini adalah rumus model penelitian:

$\operatorname{Ln} \frac{F D I}{(1-F D I)}=a+\beta_{1} X 1+\beta_{2} \mathrm{X} 2+\beta_{3} \mathrm{X} 3+\beta_{4} \mathrm{X} 4+\beta_{5} \mathrm{X} 5+\beta_{6} \mathrm{X} 6+\mathrm{e}$

\section{HASIL DAN PEMBAHASAN}

Analisis statistik deskriptif bertujuan untuk memberikan penjelasan mengenai variabel penelitian yang meliputi unit analisis penelitian $(\mathrm{N})$, nilai minimum, nilai maksimum, mean, dan standar deviasi (Ghozali, 2013). 


\begin{tabular}{lccccc}
\hline & N & Minimum & Maximum & Mean & Std. Deviation \\
\hline Likuiditas & 78 & 0,17 & 4,88 & 1,6699 & 1,01730 \\
Profitabilitas & 78 & 0,01 & 0,32 & 0,0523 & 0,06566 \\
Leverage & 78 & 0,41 & 3,13 & 1,1124 & 0,57793 \\
Peran Anggota & 78 & 0,51 & 0,81 & 0,6737 & 0,07568 \\
Kehadiran Pengurus & 78 & 0,29 & 1,00 & 0,5303 & 0,17030 \\
dalam RAT & & & & & 0,6111 \\
Kehadiran Pengawas & 78 & 0,33 & 1,00 & & 0,22258 \\
dalam RAT & 78 & & & & \\
Valid N (listwise) & & & & & \\
\hline
\end{tabular}

Pengujian menggunakan analisis regresi logistik dengan langkah - langkah menilai keseluruhan model, menguji kelayakan model, koefisien determinasi, uji multikolinearitas, matrik klasifikasi, dan estimasi parameter dan interpretasi. Hasil pengujian regresi logistik pada penelitian ditunjukkan pada tabel 4 sebagai berikut:

\begin{tabular}{clll}
\hline No. & \multicolumn{1}{c}{ Jenis Uji } & \multicolumn{1}{c}{ Hasil Uji } & \multicolumn{1}{c}{ Penjelasan } \\
\hline 1 & $\begin{array}{l}\text { Menilai Keseluruhan } \\
\text { Model }\end{array}$ & $\begin{array}{l}\text { Step } 0=90,869 \\
\text { Step } 1=57,280 \\
\text { Penurunan }=33,589\end{array}$ & Model fit dengan data. \\
\hline 2 & $\begin{array}{l}\text { Uji Kelayakan Model } \\
\text { Regresi }\end{array}$ & Sig $=0,912$ & $\begin{array}{l}\text { Model dapat diterima } \\
\text { karena lebih dari 0,05 }\end{array}$ \\
\hline 3 & Koefisien Determinasi & Adj $\mathrm{R}^{2}=0,509$ & $\begin{array}{l}50,9 \% \text { variabel independen } \\
\text { dapat menjelaskan } \\
\text { variabel dependen }\end{array}$ \\
& & & Tidak terjadi \\
& & multikolinearitas \\
\hline 4 & Uji Multikolinearitas & Koefisien korelasi & Model regresi mampu \\
& & dibawah 0,9 & memprediksi koperasi \\
\hline 5 & Tabel Klasifikasi & Non FD $=91,2$ & yang tidak financial \\
& & FD $=71,4$ & distress $91,2 \%$, koperasi \\
& & Keseluruhan $=85,9$ & yang financial distresS \\
& & & memprediksi secara \\
& & & keseluruhan 85,9\% \\
& & & \\
& & &
\end{tabular}

Tabel 4.

Hasil Uji Regresi

Logistik

Hipotesis dapat dikatakan diterima apabila nilai signifikansi dari hasil uji kurang dari 0,05. Estimasi hasil yang menunjukkan nilai koefisien dan tingkat signifikansi hasil uji hipotesis dari persamaan regresi ditampilan pada tabel 5 sebagai berikut:

\begin{tabular}{|c|c|c|c|c|}
\hline & Hipotesis & Koefisien & Sig. & Hasil \\
\hline $\mathrm{H} 1$ & $\begin{array}{l}\text { Likuiditas berpengaruh positif terhadap } \\
\text { Financial Distress }\end{array}$ & 0,455 & 0,251 & Ditolak \\
\hline $\mathrm{H} 2$ & $\begin{array}{l}\text { Profitabilitas berpengaruh negatif } \\
\text { signifikan terhadap Financial Distress }\end{array}$ & 1,387 & 0,846 & Ditolak \\
\hline H3 & $\begin{array}{l}\text { Leverage berpengaruh positif terhadap } \\
\text { Financial Distress }\end{array}$ & $-0,213$ & 0,780 & Ditolak \\
\hline $\mathrm{H} 4$ & $\begin{array}{l}\text { Peran Anggota berpengaruh negatif } \\
\text { terhadap Financial Distress }\end{array}$ & $-1,253$ & 0,809 & Ditolak \\
\hline $\mathrm{H} 5$ & $\begin{array}{l}\text { Kehadiran Pengurus dalam RAT } \\
\text { berpengaruh negatif terhadap Financial } \\
\text { Distress }\end{array}$ & $-3,408$ & 0,153 & Ditolak \\
\hline $\mathrm{H} 6$ & $\begin{array}{l}\text { Kehadiran Pengawas dalam RAT } \\
\text { berpengaruh negatif terhadap Financial } \\
\text { Distress }\end{array}$ & $-8,955$ & 0,000 & Diterima \\
\hline
\end{tabular}

Tabel 5.

Ringkasan Pengujian Hipotesis
JRAK

8,2

153

Tabel 3.

Hasil Analisis

Statistik Deskriptif 


\section{Penggunaan Rasio \\ Keuangan...}

\section{Pengaruh Likuiditas terhadap Financial Distress}

Hasil pengujian hipotesis menunjukkan bahwa likuiditas memiliki arah positif namun tidak signifikan, sehingga hipotesis pertama (H1) yang menyatakan bahwa rasio likuiditas berpengaruh positif signifikan terhadap financial distress, ditolak. Hasil pengujian dari variabel likuiditas tidak sesuai dengan implikasi teori sinyal, dimana semakin tinggi dan bertambahnya likuiditas maka semakin baik dan mampu perusahaan dalam melunasi kewajiban jangka pendeknya, sehingga perusahaan akan terhindar dari keadaan financial distress. Pengukuran likuiditas dengan menggunakan aktiva lancar akan menghasilkan nilai likuiditas yang tinggi yang menandakan bahwa koperasi tersebut dalam keadaan sehat. Akan tetapi, aktiva lancar yang tinggi mengindikasikan bahwa adanya dana yang tidak digunakan secara maksimal dan menjadi dana terpendam dalam bentuk piutang yang kemungkinan menjadi piutang tak tertagih. Hasil penelitian ini sejalan dengan penelitian Hapsari (2012), Fitriyah \& Hariyati (2013), Baimwera \& Muriuki (2014), Lakshan \& Wijekoon (2013), dan Kusanti (2015) yang menyatakan bahwa likuiditas tidak berpengaruh terhadap financial distress.

\section{Pengaruh Profitabilitas terhadap Financial Distress}

Hasil pengujian hipotesis menunjukkan bahwa profitabilitas memiliki arah positif dan tidak signifikan, sehingga hipotesis kedua (H2) yang menyatakan bahwa rasio profitabilitas berpengaruh negatif signifikan terhadap financial distress, ditolak. Hasil pengujian profitabilitas tidak sesuai dengan implikasi teori sinyal, dimana teori sinyal menjelaskan pengelola atau manajemen perusahaan memiliki tanggung jawab untuk memberikan hasil laporan keuangan dan laporan tahunan yang berisikan mengenai informasi - informasi keuangan perusahaan, dan kondisi perusahaan. Informasi yang menghasilkan sinyal baik maka akan memberikan gambaran bahwa keadaan perusahaan sedang dalam keadaan sehat, apabila pemanfaatan aset perusahaan dapat dikelola dengan baik maka akan terjadi peningkatkan pendapatan dan dapat mempengaruhi besarnya laba yang dihasilkan. Hasil analisis menunjukkan bahwa profitabilitas tidak berpengaruh terhadap $\mathrm{fi}^{-}$ nancial distress, karena adanya dugaan bahwa profitabilitas yang tinggi tidak mencerminkan efektifitas dan efesiensi pengelolaan aktiva yang dapat mengurangi biaya yang dikeluarkan oleh koperasi. Hasil penelitian ini sejalan dengan penelitian Lakshan \& Wijekoon (2013), Kusanti (2015), Hapsari (2012) dan Pranowo et al. (2010) yang menyatakan bahwa profitabilitas tidak berpengaruh terhadap financial distress.

\section{Pengaruh Leverage terhadap Financial Distress}

Hasil pengujian hipotesis menunjukkan bahwa leverage memiliki arah negatif namun tidak signifikan, sehingga hipotesis ketiga (H3) yang menyatakan bahwa rasio leverage berpengaruh positif signifikan terhadap financial distress, ditolak. Hasil pengujian leverage tidak sesuai dengan implikasi dari teori sinyal karena teori sinyal digunakan untuk memberikan petunjuk mengenai prospek perusahaan tersebut, dimana keadaan sehat atau tidak sehatnya perusahaan dapat dilihat dari laporan keuangan yang dihasilkan. Semakin banyaknya pembiayaan perusahaan yang berasal dari pendanaan hutang maka kemungkinan tidak terbayarnya hutang juga semakin tinggi, sehingga jika hutang tidak mampu dilunasi maka akan menimbulkan masalah keuangan dalam kegiatan operasional perusahaan. Nilai leverage yang tinggi belum tentu menjamin koperasi terkena financial distress karena koperasi yang memiliki nilai leverageyang tinggi belum tentu memiliki beban yang tinggi dan menghasilkan laba yang rendah. Kemungkinan lainnya 
adalah nilai leverage yang meningkat, tidak meningkatkan beban yang dihasilkan oleh koperasi sehingga koperasi tidak mengalami financial distress karena sisa hasil usaha yang diperoleh koperasi tetap stabil atau lebih meningkat dari sebelumnya. Hasil penelitian ini sejalan dengan penelitian Baimwera \& Muriuki (2014), Kusanti (2015), Aisyah, Kristanti, \& Zultilisna (2017), dan Hadi (2014) menyatakan bahwa leverage tidak berpengaruh terhadap financial distress.

\section{Pengaruh Peran Anggota terhadap Financial Distress}

Hasil pengujian hipotesis menunjukkan bahwa peran anggota memiliki arah negatif dan tidak signifikan, sehingga pada hipotesis keempat (H4) yang menyatakan bahwa peran anggota berpengaruh negatif signifikan terhadap financial distress, ditolak. Hasil dari pengujian peran anggota tidak sesuai dengan implikasi teori agensi, dimana teori ini menjelaskan adanya hubungan kontrak antara pemilik dengan pengelola perusahaan. Pada koperasi kemungkinan pemilik modal yang juga sebagai anggota dan pengelola koperasi kurang memaksimalkan penerapan good corporate governance. Jika pemilik dan pengelola (agen) tidak mengambil keputusan secara tepat dan lemahnya hubungan antara principals dengan agennya maka kurangnya pengawasan pada keuangan dalam koperasi. Pengaruh peran anggota dalam koperasi tidak dapat digunakan untuk memprediksi financial distress pada koperasi. Jadi, ketika koperasi memiliki anggota yang aktif dalam jumlah banyak dan memiliki pendapatan dari piutang dalam jumlah besar belum tentu koperasi tersebut akan mengalami financial distress di masa yang akan datang. arah hubungan negatif sejalan dengan penelitian dari Cahyani (2015) yang menyatakan bahwa adanya hubungan tidak langsung antara partisipasi anggota dengan peningkatan SHU.

\section{Pengaruh Kehadiran Pengurus dalam Rapat Anggota Tahunan terhadap Financial Distress}

Hasil pengujian hipotesis menunjukkan bahwa kehadiran pengurus dalam RAT memiliki arah negatif namun tidak signifikan, sehingga pada hipotesis kelima (H5) yang menyatakan bahwa khadiran pengurus dalam RAT berpengaruh negatif signifikan terhadap financial distress, ditolak. Hasil dari pengujian kehadiran pengurus dalam RAT tidak sesuai dengan implikasi teori agensi yang mendeskripsikan hubungan antara pihak manajemen dan pemilik yang memicu terjadinya konflik dalam organisasi. Konflik tersebut dapat diminimalisir dengan adanya corporate governance yang baik, sehingga diharapkan dengan corporate governance yang baik dapat digunakan untuk meningkatkan motivasi kerja yang baik dalam mengelola koperasi oleh para pengurus koperasi. Pada hasil penelitian Li et al. (2008) menyatakan bahwa direktur independen berpengaruh signifikan terhadap financial distress. Hal ini berbeda dengan hasil yang menunjukkan bahwa peran pengurus tidak berpengaruh signifikan terhadap financial distress. Jadi, seberapa banyak pengurus yang aktif dalam mengikuti rapat untuk membahas dan mempertanggungjawabkan hasil laporan keuangan dalam koperasi tidak dapat mempengaruhi prediksi financial distress dimasa sekarang ataupun mendatang.

\section{Pengaruh Kehadiran Pengawas dalam Rapat Anggota Tahunan terhadap Financial Distress}

Hasil pengujian hipotesis menunjukkan bahwa kehadiran pengawas dalam RAT memiliki arah negatif dan signifikan, sehingga pada hipotesis keenam (H6) yang menyatakan bahwa kehadiran pengawas dalam RAT berpengaruh negatif signifikan terhadap financial distress, diterima. Hasil dari pengujian kehadiran pengawas dalam RAT koperasi implikasinya sesuai dengan teori agensi yang menjelaskan bahwa adanya hubungan antara principals dengan agen dapat memicu 
Penggunaan

Rasio

Keuangan...

156

timbulnya konflik, dimana konflik tersebut dapat diminimalisir dengan adanya penerapan good corporate governance. Semakin baik corporate governance yang diterapkan dalam koperasi maka semakin baik pula pengawas dalam memonitoring kinerja para pengurus. Hasil penelitian ini menunjukkan bahwa semakin tinggi pengawas yang hadir dalam rapat, maka meningkatkan monitoring dan evaluasi terhadap kinerja pengurus. Jadi, dapat disimpulkan bahwa pengawas pada koperasi yang dijadikan sampel telah memanfaatkan fungsi monitoring secara maksimal, sehingga pengurus dalam koperasi juga melakukan tugasnya dengan baik dan mampu meminimalisir terjadinya kesalahan, kecurangan, serta masalah keuangan. Pengukuran dari peran pengawas diproksikan sebagai dewan komisaris yang mana hasil penelitian ini sejalan dengan penelitian Hadi (2014) dan Fathonah (2016).

\section{SIMPULAN}

Simpulan dari penelitian ini likuiditas memiliki arah hubungan positif namun tidak signifikan terhadap financial distress, profitabilitas memiliki arah hubungan positif namun tidak signifikan terhadap financial distress, leverage memiliki arah hubungan negatif dan tidak signifikan terhadap financial distress, peran anggota memiliki arah hubungan negatif dan tidak signifikan terhadap financial distress, kehadiran pengurus dalam RAT memiliki arah hubungan negatif dan tidak signifikan terhadap financial distress, dan kehadiran pengawas dalam RAT memiliki arah hubungan negatif dan signifikan terhadap financial distress.

Saran untuk pihak koperasi diharapkan mampu mengembangkan model prediksi financial distress dalam laporan keuangannya sehingga dapat dilakukannya pembinaan awal untuk meminimalisir terjadinya financial distress. Selain itu, sebaiknya pihak koperasi lebih memaksimalkan penerapan good corporate governance. Saran untuk pengurus dan pengawas diharapkan mampu meningkatkan kualitas kinerja dan melakukan evaluasi kinerja untuk meminimalisir terjadinya kecurangan, kesalahan dan financial distress dalam koperasi. Saran untuk peneliti selanjutnya diharapkan melakukan penambahan pengukuran rasio yang tepat pada koperasi, lebih memperdalam penerapan good corporate governance pada koperasi, dan menambah obyek selain koperasi simpan pinjam.

\section{DAFTAR PUSTAKA}

Aisyah, N. N., Kristanti, F. T., \& Zultilisna, D. (2017). Pengaruh Rasio Likuiditas, Rasio Aktivitas, Rasio Profitabilitas, dan Rasio Leverage Terhadap Financial Distress. E-Proceeding of Management, Vol. 4, No.1.

Almilia, L. S., \& Kristijadi, E. (2003). Analisis Rasio Keuangan Untuk Memprediksi Kondisi Financial Distress Perusahaan Manufaktur Yang Terdaftar di Bursa Efek Jakarta. Jurnal Akuntansi \& Auditing Indonesia.

Anthony, R. N., \& Govindarajan, V. (2005). Management Control System. Jakarta: Salemba Empat.

Asquith, P., Gertner, R., \& Scharfstein, D. (1994). Anatomy of Financial Distress: An Examination of Junk-Bond Issuers. The Quarterly Journal of Economics, Vol 109, No. 3.

Baimwera, B., \& Muriuki, A. M. (2014). Analysis of Corporate Financial Distress Determinants/: a Survey of Non-Financial Firms Listed in the Nse. International Journal of Current Business and Social Sciences, Vol 1, No.2.

Brigham, E. F., \& Houston, J. F. (2013). Dasar - Dasar Manajemen Keuangan. Jakarta: Salemba Empat.

Cahyani, M. T. (2015). Pengaruh Jumlah Anggota Terhadap Perolehan Sebagai Variabel Intervening Pada Koperasi Simpan Pinjam Wisuda Guna Raharja 
Denpasar Tahun 2012-2014. Jurusan Pendidikan Ekonomi (JJPE), Vol 5, No. 1.

Fathonah, A. N. (2016). Pengaruh Penerapan Good Corporate Governance

Terhadap Financial Distress. Jurnal Ilmiah Akuntansi, 1(2).

Finnerty, J. D. (1986). Corporate Financial Analysis. McGraw-Hill International Edition.

Fitriyah, I., \& Hariyati. (2013). Pengaruh Rasio Keuangan Terhadap Financial Distress Pada Perusahaan Properti Dan Real Estate. Jurnal Ilmu Manajemen, Vol. 1, No.3.

Ghozali, I. (2013). Aplikasi Analisis Multivariate Dengan Program IBM SPSS 21. Semarang: FE Universitas Diponegoro.

Habibi, M. H. (2017). Koperasi Banyak yang Gulung Tikar. Diunduh di https:// www.kompasiana.com/hamid.hab2/59675ee9986bdb28af51f4d2/koperasibanyak-yang-gulung-tikar tanggal 30 Januari 2018.

Hadi, S. A. F. (2014). Mekanisme Corporate Governance Dan Kinerja Keuangan Pada Perusahaan Yang Mengalami Financial Distress. Jurnal Ilmu Dan Riset Akuntansi, 3(5).

Hanifah, O. E., \& Purwanto, A. (2013). Pengaruh Struktur Corporate Governance Dan Financial Indicators Terhadap Kondisi Financial Distress. Diponegoro Journal of Accounting, 2.

Hapsari, E. I. (2012). Kekuatan Rasio Keuangan Dalam Memprediksi Kondisi Financial Distress Perusahaan Manufaktur Di BEI. Jurnal Dinamika Manajemen, Vol.3, No.2.

Haryadi, M. (2017). 100 Koperasi di Semarang Akan Dibubarkan, Ini Alasannya. Diunduh di http://www.tribunnews.com/regional/2017/02/03/100-koperasi-disemarang-akan-dibubarkan-ini-alasannya tanggal 30 Januari 2018.

Hery. (2015). Analisis Laporan Keuangan. Yogyakarta: CAPS.

Iskandar, Bintang K. (2015). Analisa Penerapan Prinsip - Prinsip Good Corporate Governance dan Pengendalian Internal. Jurnal Ilmu \& Riset Akuntansi, Vol.4, No.10.

Kusanti, O. (2015). Pengaruh Good Corporate Governance Dan Leverage. Jurnal Ilmu \& Riset Akuntansi, Vol.4, No.10.

Lakshan, A. M. I.., \& Wijekoon, W. M. H.. (2013). The Use of Financial Ratios in Predicting Corporate Failure in Sri Lanka. GSTF Journal on Business Review, Vol 2, No.4.

Li, H., Wang, Z., \& Deng, X. (2008). Ownership, independent directors, agency costs and financial distress: evidence from Chinese listed companies. Corporate Governance: The International Journal of Business in Society, Vol 8, No.5.

Platt, H. D., \& Platt, M. B. (2002). Predicting corporate financial distress: Reflections on choice-based sample bias. Journal of Economics and Finance, Vol. 26, No.2.

Pranowo, K., Achasani, N. A., \& Manurung, A. H. (2010). Determinant of Corporate Financial Distress in an Emerging Market Economy/: Empirical Evidence from the Indonesian Stock Exchange 2004-2008. International Research Journal of Finance and Economics, Vol 52, No.52.

Rahmawati, D., \& Khoiruddin, M. (2017). Pengaruh Corporate Governance dan Kinerja Keuangan Dalam Memprediksi Kondisi Financial Distress. Management Analysis Journal, Vol. 6, No.1.

Scott, W. R. (2012). Financial Accounting Theory sixth edition. Canada: Pearson Canada Inc.

Simanjutak, C., Farida, T., \& Aminah, W. (2017). Pengaruh Rasio Keuangan Terhadap Financial Distress (Studi Pada Perusahaan Transportasi Yang 
Penggunaan

Rasio

Keuangan...
Terdaftar Di Bursa Efek Indonesia Periode 2011 - 2015). E-Proceeding of Management, Vol. 4, No.2.

Suhartiningsih, N. N. T., \& Wirawati, N. G. P. (2017). Prediksi Financial Distress Pada Koperasi Simpan Pinjam Di Kabupaten Badung. E-Jurnal Akuntansi Universitas Udayana, Vol.18, No.1.

Sukirno, Haryadi, \& Budiarti, L. (2014). Prediksi Financial Distress Pada Koperasi Di Kabupaten Pemalang. Jurnal Akuntansi \& Auditing, Vol.10, No.2.

Uðurlu, M., \& Aksoy, H. (2006). Prediction of corporate financial distress in an emerging market: the case of Turkey. Cross Cultural Management: An International Journal, Vol 13, No.4.

Widhianningrum, P., \& Amah, N. (2012). Pengaruh Mekanisme Good Corporate Governance Terhadap Kinerja Keuangan Selama Krisis Keuangan Tahun 2007 - 2009. Jurnal Dinamika Akuntansi, Vol 4, No.2.

Widyasaputri, E. (2012). Analisis Mekanisme Corporate Governance Pada Perusahaan yang Mengalami Kondisi Financial Distress. Accounting Analysis Journal, Vol. 1, No.2.

Yokono. (2016). 7 Perusahaan Bangkrut di Indonesia. Diunduh di https:// www.kaskus.co.id/thread/56b2b1db529a45ff798b456a/7-perusahaanbangkrut-di-indonesia/ tanggal 30 Januari 2018.

Zaki, E., Bah, R., \& Rao, A. (2011). Assessing probabilities of financial distress of banks in UAE. International Journal of Managerial Finance, Vol.7, No.3. 